\title{
ANALISIS FAKTOR INDIVIDU YANG BERHUBUNGAN DENGAN KELUHAN MUSKULOSKELETAL (Musculosceletaldisorders/MSD) BIDAN DALAM PERTOLONGAN PERSALINAN DI PUSKESMAS WILAYAH KERJA I DINKES KABUPATEN LEBAK
}

\author{
Hani Sutianingsih, Yayah Rokayah \\ Poltekkes Kemenkes Banten \\ Korespondensi: hanisutianingsih@gmail.com
}

\begin{abstract}
Midwives experience occupational risks when performing labor assistance which can result in musculoskeletal disorders (MSD). Bone and Joint Decade Model summarizes several factors that cause MSD, one of which is individual factors that have a large influence on MSD events. This research is descriptive analytic with a sample of 92 midwives working in the Puskesmas in the working area I Lebak District. The MSD score assessment was carried out through the Nordic Musculosceletal Questionnaire that measures MSD complaints based on personal reports that have been widely recognized and used for MSD epidemiological research and workplace health surveillance. Statistical testing to see the relationship between individual factors and MSD was carried out using the Chi-square test, while to see the risk of use on each individual factor was done by looking at the OR values in the Chi-Square test. The significance value is set at $p<0.05$. The results showed that there was a relationship between age and working period with complaints of midwives MSD in performing labor delivery $(p<0.05)$ and there was no relationship between BMI, sleep duration, perception of general health and psychological conditions with complaints of midwives in childbirth assistance ( $p>0.05)$.
\end{abstract}

Keywords: Midwives, Individual Factors, MSD, childbirth assistance

\begin{abstract}
ABSTRAK
Bidan mengalami risiko pekerjaan saat melakukan pertolongan persalinan yang dapat berakibat pada terjadinya gangguan musculoskeletal (Musculosceletal Disorders/MSD). Bone and Joint Decade Model merangkum beberapa faktor penyebab terjadinya MSD, salah satunya adalah faktor individu yang memiliki pengaruh yang besar terhadap kejadian MSD. Penelitian ini bersifat deskriptif analitik dengan jumlah sampel 92 bidan yang bekerja di Puskesmas wilayah kerja I Kab. Lebak Penilaian skor MSD dilakukan melalui Nordic Musculosceletal Questionnaire yang mengukur keluhan MSD berdasarkan laporan pribadi yang telah diakui dan digunakan secara luas untuk riset epidemiologi MSD dan surveilens kesehatan di tempat kerja. Pengujian statistik untuk melihat hubungan antara faktor individu dengan MSD dilakukan dengan menggunakan uji Chi-kuadrat, sementara untuk melihat resiko penggunaan pada setiap faktor individu dilakukan dengan melihat nilai OR pada uji Chi-Kuadrat. Nilai kemaknaan ditentukan sebesar $\mathrm{p}<0,05$. Hasil penelitian menunjukan terdapat hubungan antara umur dan masa kerja dengan keluhan MSD bidan dalam pertolongan persalinan $(\mathrm{p}<0,05)$ dan tidak
\end{abstract}


terdapat hubungan antara IMT, lama tidur, persepsi kesehatan umum dan kondisi psikologis dengan keluhan MSD bidan dalam pertolongan persalinan ( $p>0,05)$.

\section{Kata kunci: Bidan , Faktor Individu, MSD, pertolongan persalinan}

\section{PENDAHULUAN}

Profesi bidan merupakan salah satu profesi yang memerlukan banyak skill, karena bidan menanggung tingginya tingkat ekspektasi kinerja dan profesionalitas dari masyarakat, walaupun dengan durasi waktu bekerja yang relatif lama dan tidak teratur, bidan tetap dituntut untuk dapat memberikan performa kinerja yang baik. Sebuah studi menyebutkan bahwa tuntutan profesi bidan yang tinggi dapat menjadi penyebab utama terjadinya stress karena pekerjaan selain rendahnya status kesehatan dan 'gesekan' yang datang dari profesinya sendiri. Bidan juga berisiko menghadapi beberapa bahaya kesehatan dalam pekerjaannya seperti keterpajanan terhadap penyakit infeksi, tuntutan psikologis, waktu kerja shift serta risiko dari pekerjaan yang dialami oleh bidan. ${ }^{(1),(2)}$

Risiko pekerjaan dari pekerjaan bidan adalah keluhan otot rangka yang biasa disebut dengan Musculosceletal disorders/MSD, bahkan petugas kesehatan menempati urutan tertinggi dalam keluhan MSD. Sebuah studi di Australia menyebutkan mengenai gangguan muskuloskeletal yang dirasakan bidan saat bekerja sebanyak $48,8 \%$ pada leher, $61,2 \%$ punggung bawah dan 29,2 \% pada punggung atas. Keluhan mengenai MSD pada bidan di Kabupaten Serang menunjukkan bahwa bidan mengalami keluhan otot skeletal pada saat melakukan pertolongan persalinan, seperti adanya keluhan sakit leher (84\%), bahu (79\%), punggung atas(74\%), pinggul (58\%), lutut (53\%), kaki (47\%), punggung bawah $(37 \%)$, pergelangan tangan $(26 \%)$,dan siku $(11 \%){ }^{(3),(4),(5)}$

Bone and Joint Decade Model merangkum beberapa faktor penyebab terjadinya MSD, seperti faktor individu dan faktor pajanan ditempat kerja, keduanya memiliki pengaruh yang besar terhadap kejadian MSD seperti terlihat pada penelitian Trinkoff yang menyebutkan terdapat hubungan positif antara umur dan jenis kelamin dengan keluhan otot, selain itu gaya hidup (merokok, konsumsi alkohol dan olahraga) mempengaruhi terjadinya MSD sebesar 2 kali. Fakta menunjukan bahwa interaksi antara beberapa faktor risiko MSD akan menyebabkan kejadian MSD lebih tinggi dibanding dengan hanya satu faktor risiko. ${ }^{(4)}$

Sifat gangguan muskuloskeletal/MSD cenderung muncul perlahan dan seringkali diabaikan oleh bidan, bahkan hal ini berpengaruh pada konsekuensi fungsional bidan dalam pekerjaannya. Penelitian di Australia menyebutkan bahwa proporsi 
bidan yang mengajukan cuti sakit karena gangguan muskuloskeletal pada daerah leher sebanyak 20,9\%, daerah punggung bawah sebanyak $23,8 \%$ dan $17,1 \%$ pada punggung atas, bahkan gangguan muskuloskeletal dapat menyebabkan ketidakmampuan fungsional ditempat kerja antara $50-60 \%{ }^{(6)}$

Dampak yang ditimbulkan dari keluhan MSD pada bidan sangatlah besar, selain kurang produktif, bidan akan mengalami kekurangan konsentrasi dalam menjalankan tugas, lebih mudah mengalami kesalahan dan kecelakaan kerja. Data mengenai keluhan MSD pada bidan di kabupaten lebak belum tersedia, namun dari jumlah persalinan terlihat bahwa sebanyak 72\% persalinan telah ditolong oleh bidan, dengan persentase yang besar ini dapat disimpulkan bahwa risiko seorang bidan dalam mengalami keluhan MSD di Kabupaten lebak sangatlah besar $^{(7)}$ Sehingga penelitian untuk melihat faktor individu apa saja yang berhubungan dengan keluhan MSD bidan saat pertolongan persalinan di Kabupeten Lebak sangatlah dibutuhkan, agar dapat meminimalisir dampak dari kejadian MSD dikemudian hari.

\section{METODE}

Desain penelitian ini adalah penelitian deskriptif analitik dengan menggunakan pendekatan cross sectional. Penelitian dilakukan untuk menilai hubungan faktor risiko individu terhadap keluhan otot rangka (Musculosceletal disorders/MSD) berdasarkan konsep teori dari Bone and Joint Decade Model tahun 2010.

Penelitian ini terdiri dari 2 (dua) variabel, yakni variabel bebas (Independen) dan variabel terikat (Dependen). Variabel bebas atau independen dalam penelitian ini adalah faktor individu yang terdiri dari foundational factors (umur, masa kerja), developmental factors (merokok, aktifitas fisik, jam tidur, IMT, aktifitas fisik, kondisi kesehatan umum, kondisi psikologis). Jumlah responden pada penelitian ini sebesar 92 orang yang terdiri dari bidan yang bekerja di Puskesmas wilayah I kab. Lebak. 


\section{HASIL DAN PEMBAHASAN}

\section{Grafik 1. Keluhan MSD terkait pekerjaan bidan dalam 12 bulan terakhir}

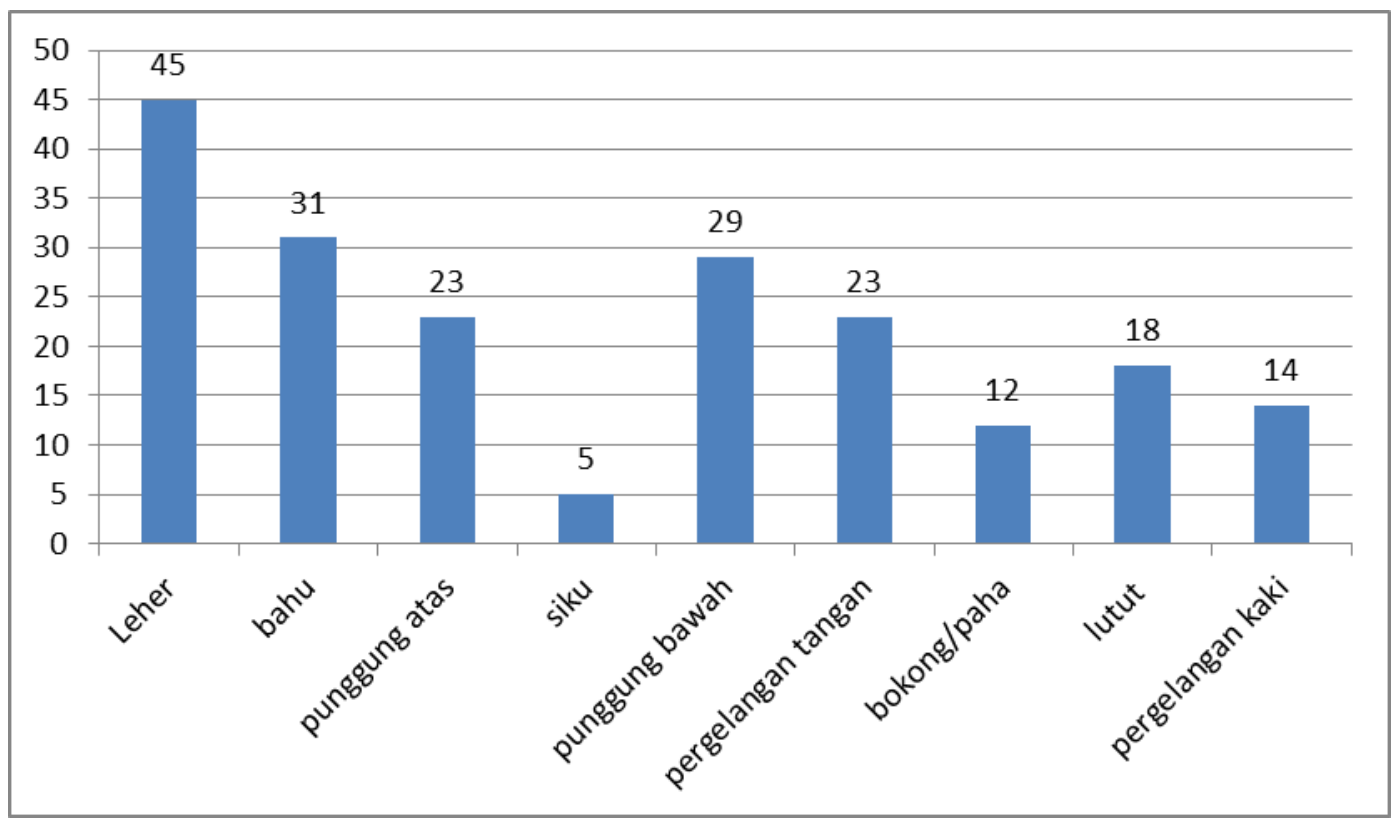

Pada penelitian ini didapatkan sebanyak 79\% bidan mengalami keluhan MSD terkait pekerjaannya. Dari distribusi keluhan MSD terdapat empat bagian tubuh yang paling banyak dikeluhkan MSD dalam pertolongan persalinan yaitu bagian leher sebanyak $48,9 \%$, bahu $33,7 \%$, punggung bawah $31,5 \%$ dan pergelangan tangan $25 \%$. Selama proses persalinan bidan banyak melakukan aktifitas yang berisiko menimbulkan MSD seperti aktifitas berisiko pada kala I yang disebutkan dalam penelitian stichler, dkk yaitu pemeriksaan dalam dan pemeriksaan DJJ yang memperlihatkan postur janggal yang sering dikerjakan bidan seperti leher yang menekuk, bahu yang terputar dan punggung bawah yang membungkuk, serta pergelangan tangan yang menekuk. ${ }^{(12)}$ Pada Kala II dan kala III persalinan, bidan akan membungkukan badan menyesuaikan dengan ketinggian tempat tidur bersalin, leher dan bahu akan menekuk menyesuaikan dengan jalan lahir dan pergelangan tangan akan menekuk menyesuaikan dengan lahirnya bayi. Hal ini akan menyebabkan sikap kerja yang tidak ergonomis, yang akan mengakibatkan adanya ketidakselarasan pada segmen tulang belakang serta adanya ketidakstabilan postur. ${ }^{(13)}$ 
Pada beberapa kasus di Kala IV persalinan yang disertai laserasi perineum, mengharuskan bidan untuk menjahit perineum dengan kondisi membungkuk dan duduk dalam waktu yang relative lama. Hal ini akan menyebabkan bidan melakukan sikap kerja yang tidak ergonomis berupa sikap tubuh yang membungkuk kedepan leher dan bahu yang menyesuaikan dengan tempat tidur bersalin dan pergelangan tangan yang bergerak dan berputar tidak sesuai sumbunya (postur janggal). Postur janggal dapat menyebabkan otot tidak dapat bekerja secara efisien, oleh karena itu otot memerlukan energi lebih untuk dapat menyelesaikan tugasnya. Hal ini dapat menyebabkan kelelahan dan ketegangan pada otot dan tendon. Postur janggal yang statis dapat menyebabkan meningkatnya tekanan pada otot. Tekanan pada otot dalam waktu yang lama akan menyebabkan terjadinya iskemik (penurunan aliran darah ke jaringan otot), yang berakibat berkurangnya asupan oksigen, meningkatnya karbondioksida dan zat sampah lainnya seperti asam laktat. Penumpukan asam laktat di otot inilah yang menyebabkan timbulnya keluhan nyeri otot/ MSD.
Di Indonesia, postur janggal/sikap kerja tidak alamiah yang menyebabkan keluhan MSD lebih banyak diakibatkan oleh adanya ketidaksesuaian antara dimensi alat dan stasiun kerja dengan ukuran tubuh pekerja. ${ }^{(8)}$ Sikap kerja tidak alamiah bila dilakukan secara terus menerus (repetitif) akan menyebabkan gangguan otot pada daerah kuadran atas /punggung atas (work related upper quadran musculosceletal disorders), seperti yang diungkapkan Long dalam ulasan sistematisnya bahwa postur janggal/sikap kerja tidak alamiah akan berisiko menyebabkan gangguan muskuloskeletal sebanyak 2 kali pada daerah leher, bahu dan punggung atas. ${ }^{(4)}$

Menurut salah satu studi mengenai patofisiologi ketidaknyamanan menyebutkan bahwa penggunaan tenaga, repetisi, dan postur janggal dapat menjadi salah satu faktor penyebab beban fisik pekerjaan seseorang serta posisi seseorang dalam bekerja akan mempengaruhi postur tubuhnya pada saat melakukan aktifitas kerja. Postur kerja yang janggal bila dilakukan secara terus menerus dapat menyebabkan ketidaknyamanan dan gangguan muskuloskeletal (musculosceletal disorders/MSD). ${ }^{(15)}$ 
Tabel 1. Hubungan antara Faktor Individu (Foundational Factors) dengan keluhan MSD bidan dalam pertolongan persalinan di Puskesmas wilayah kerja I Dinkes Kab. Lebak.

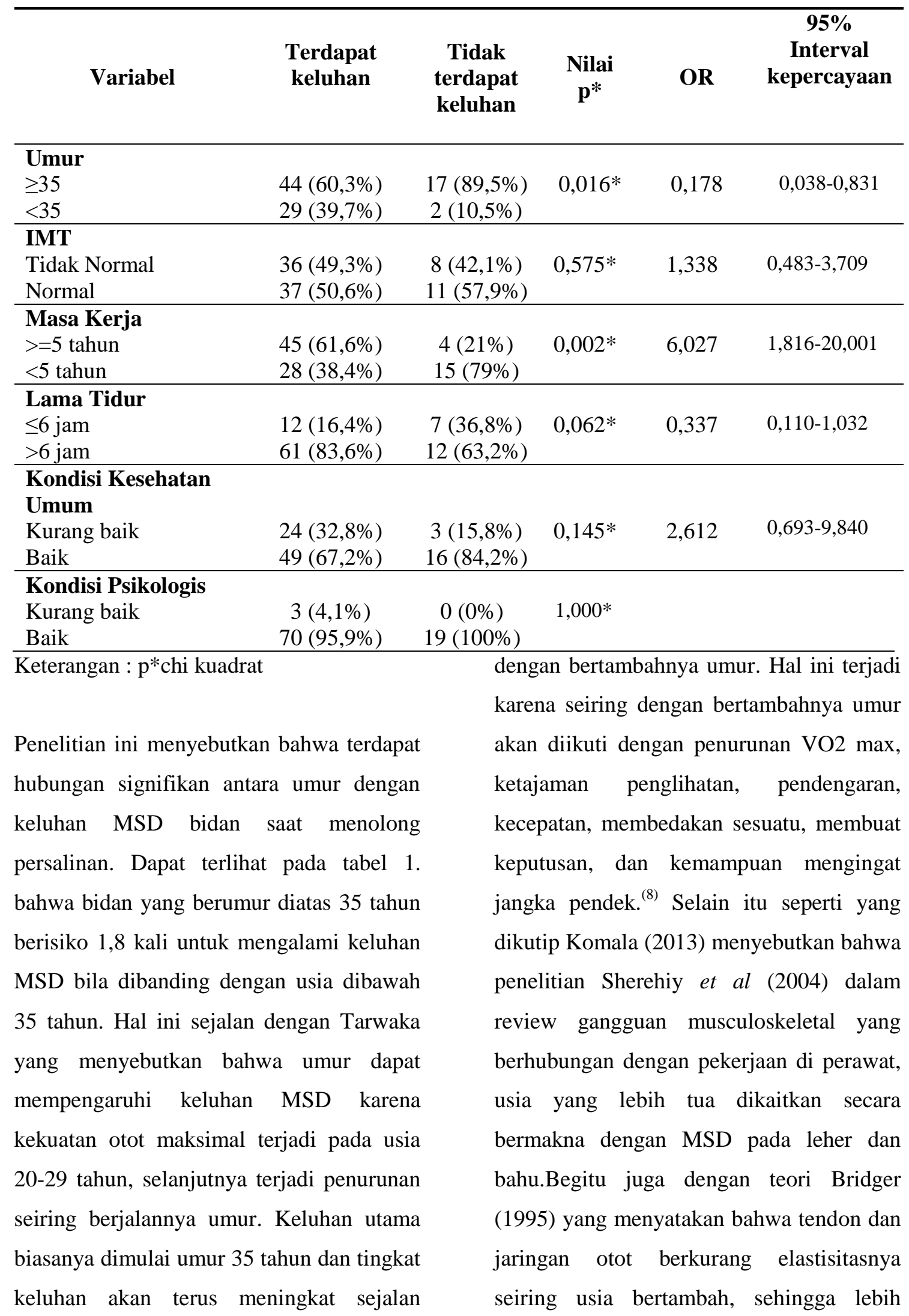


berisiko timbulnya keluhan MSD. Sedangkan menurut Hettinger dalam Kroemer dan Grandjean (1997), puncak kekuatan otot baik pada perempuan maupun laki-laki adalah pada rentang usia 25-35 tahun.

Pada pekerja dengan rentang usia 50-60 tahun hanya dapat menghasilkan $75-85 \%$ dari kekuatan otot. Brown et al. (2007) menyatakan bahwa hingga usia awal 30an, tulang secara bertahap bertambah padat. Namun setelah usia ini, tulang mulai dirombak lebih cepat daripada penggantinya sehingga kepadatan tulang menurun. Pada usia 30 tahun terjadi degenerasi yang berupa kerusakan jaringan, pergantian jaringan menjadi jaringan parut, pengurangan cairan. Keadaan ini menyebabkan stabilitas pada otot dan tulang berkurang (Mutiah et al., 2013). ${ }^{(3)}$

Penelitian ini tidak menemukan adanya hubungan antara indeks masa tubuh (IMT) dengan keluhan MSD pada bidan dalam pertolongan persalinan. Meskipun berat badan, tinggi badan dan massa tubuh merupakan faktor yang dapat menyebabkan terjadinya MSD dan wanita yang gemuk mempunyai resiko dua kali lipat dibandingkan wanita kurus. Serta orang yang gemuk (obesitas dengan masa tubuh >29) mempunyai resiko 2,5 lebih tinggi dibandingkan dengan yang kurus (masa tubuh <20), namun hal ini masih merupakan faktor yang memiliki pengaruh yang relative kecil, seperti diungkapkan
Tarwaka bahwa ukuran antropometri memiliki pengaruh relative kecil dalam menimbulkan keluhan MSD. ${ }^{(8)}$ Selain itu seperti yang dikutip Komala (2013) menyebutkan bahwa Noorloos et al.(2008) melakukan penelitian mengenai hubungan IMT dengan risiko terjadinya Low Back Pain (LBP) menghasilkan simpulan bahwa tidak terdapat hubungan yang signifikan antara IMT dengan timbulnya LBP baik dalam 7 hari terakhir $(\mathrm{r}=0,07 \mathrm{p}=0,34)$ maupun 12 bulan terakhir $(\mathrm{r}=-0,30$ $\mathrm{p}=0,63){ }^{(3)}$

Penelitian ini menyebutkan bahwa terdapat hubungan yang signifikan antara masa kerja dengan keluhan MSD saat pertolongan persalinan. Seperti terlihat pada tabel 1 . Bahwa bidan yang memiliki masa kerja lebih dari 5 tahun memiliki risiko 6,027 kali bila dibanding dengan bidan yang memiliki masa kerja dibawah 5 tahun. Hal ini sesuai dengan penelitian Komala (2013) yang menyebutkan bahwa masa kerja lebih dari lima tahun akan meningkatkan risiko terjadinya low back pain dibandingkan masa kerja kurang dari 5 tahun pajanan. ${ }^{(3)}$ Hal ini dikarenakan pembebanan tulang belakang dalam waktu yang lama mengakibatkan rongga diskus menyempit secara permanen dan mengakibatkan degenerasi tulang belakang yang akan menimbulkan nyeri punggung bawah kronis. Selain itu dapat dipahami bahwa seseorang dengan masa kerja yang lama akan mengalami keluhan yang fatal jika 
dibandingkan pekerja yang baru pertama kali bekerja.

Penelitian ini menyebutkan bahwa tidak terdapat hubungan yang signifikan antara lama tidur bidan dalam sehari dengan keluhan MSD dalam pertolongan persalinan. Bila dilihat dari segi teori, hal ini tidak sesuai, karena shift kerja bidan akan mempengaruhi lama tidur bidan yang akan meningkatkan stress saat bekerja, yang akan berpengaruh pada keluhan MSD. Lamanya waktu tidur akan terkait dengan ritme sirkadian (circadian rhitym) yaitu penyesuaian proses dalam tubuh yang berritme teratur selama 24 jam, seperti metabolisme hati, laju pernafasan, suhu tubuh, ekskresi hormone dan produksi urine. Kroemer dan Gradjen menyatakan bahwa fungsi paling penting yang menopang ritme sirkadian berjalan optimal adalah tidur. Memiliki jam tidur yang cukup merupakan syarat fundamental bagi kesehatan tubuh, kesejahteraan dan efisiensi fungsi tubuh. Seorang manusia dewasa memerlukan waktu tidur sekitar 6-8 jam setiap malamnya. Kurang tidur, baik dalam kuantitas maupun kualitas berhubungan dengan pemulihan kondisi tubuh yang tidak optimal, dapat mengakibatkan kelelahan kronis yang berdampak timbulnya keluhan pada sistem syaraf dan pencernaan. ${ }^{(8)}$ Apabila bidan bekerja shift dan terganggu waktu tidurnya selama kurang lebih 3 minggu berturut-turut, maka tubuh akan memerlukan waktu untuk menormalkan kembali ritme tubuhnya selama kurang lebih 1 minggu penuh. Pada penelitian ini tidak memperlihatkan adanya kesesuaian dengan teori, hal ini dapat disebabkan oleh kurangnya responden yang terlibat dalam penelitian.

Kondisi kesehatan umum yang dinilai pada penelitian ini adalah persepsi diri terhadap kondisi kesehatan umum dirinya, sehingga banyak sekali subjektifitas yang terjadi, hal ini bisa menjadi salah satu faktor yang menimbulkan tidak adanya hubungan antara persepsi kondisi kesehatan umum dengan keluhan MSD saat pertolongan persalinan. Hasil penelitian ini tidak sejalan dengan penelitian Alexopoulos menyebutkan bahwa persepsi diri mengenai kondisi kesehatan umum merupakan faktor risiko terjadinya MSD pada daerah leher ( OR: 8,31), punggung (OR : 2,03), dan bahu (OR:6,84) yang mengakibatkan ketidakhadiran perawat di tempat kerja. ${ }^{(16)}$ Penelitian ini menghasilkan data bahwa tidak terdapat hubungan yang signifikan antara kondisi psikologis dengan keluhan MSD, hal ini dapat disebabkan oleh sebagian besar bidan berada pada kondisi psikologis yang baik yaitu sebanyak 89 orang $(96,7 \%)$, sehingga tidak dapat di komparasi. Namun bila ditelaah kembali dari 89 orang bidan dengan kategori kondisi psikologis yang baik sebagian besar (70 orang) mengalami keluhan MSD saat pertolongan. Hal ini sesuai dengan penelitian yang dilakukan Bru et al (1993) 
yang menyimpulkan bahwa dua ciri kepribadian, yaitu neurotisisme dan untuk tingkat yang lebih rendah yaitu lekas marah, berhubungan dengan nyeri leher dan bahu pada bidan. Namun hasil ini berbeda dengan Szeto et al.(2009) yang menemukan bukti bahwa workstyle, suatu bentuk kategori faktor psikologis individu, tidak terkait dengan nyeri leher dan ekstremitas atas pada pada dokter bedah umum (Long H. et al, 2012). ${ }^{(3)}$

Dalam ruang bersalin, emosi kerap kali hadir, mulai dari rasa cemas sampai rasa frustrasi.Sementara di luar ruang bersalin, bidan mungkin saja menghadapi perselisihan, penilaian keterampilan klinis yang tak jarang menimbulkan pertanyaan yang tidak beralasan, atau kekerasan lainnya antar rekan kerja (Curtis et al, 2006). Dalam hal ini, tekanan stressor yang tinggi di ruang bersalin, akan semakin memperparah risiko timbulnya keluhan MSD pada bidan terutama mereka yang memiliki faktor psikologis individu cenderung negatif. ${ }^{(3)}$

\section{SIMPULAN}

Penelitian ini menyimpulkan bahwa terdapat hubungan antara factor individu (foundational factors) berupa umur, dan masa kerja terhadap keluhan MSD, sementara untuk factor IMT, lama tidur, persepsi kesehatan umum dan kondisi psikologis tidak memiliki hubungan dengan keluhan MSD.

\section{UCAPAN TERIMA KASIH}

Terimakasih kepada para contributor yang telah berpartisipasi pada penelitian ini, para bidan yang bekerja di Puskesmas wilayah I Dinas kesehatan Kabupaten Lebak.

\section{DAFTAR PUSTAKA}

1. Schluter PJ, Turner C, Huntington AD, Bain CJ, McClure RJ. Work/life balance and health: The Nurses and Midwives e-cohort study. Int Nurs Rev. 2011;58(1):28-36.

2. Hignett $S$. Identification of Risk Factors. 1996;4(11):590-6.

3. Komala R, Modjo R. Faktor-Faktor Yang Berhubungan Terhadap Keluhan Musculoskeletal Disorders ( MSDs ) Pada Bidan Di Pusat Kesehatan Masyarakat Dengan Tempat Bersalin ( Puskesmas DTP ) Kota Bandung Tahun 2013. 2013;1-19.

4. Long MH, Johnston V, Bogossian F. Work-related upper quadrant musculoskeletal disorders in midwives, nurses and physicians: A systematic review of risk factors and functional consequences. Appl Ergon [Internet]. Elsevier Ltd; 2012;43(3):455-67. Available from: http://dx.doi.org/10.1016/j.apergo.2011. 07.002

5. Wajdi F, Cahyadi D. analisis keluhan fisik bidan akibat menolong partus. 2016;(November):1-7.

6. Long MH, Bogossian FE, Johnston V. Functional consequences of workrelated spinal musculoskeletal symptoms in a cohort of Australian midwives. Women and Birth. Australian College of Midwives; 2013;26(1):e50-8.

7. Banten DKP. Resume Profil Kesehatan Tahun 2015. 2015.

8. Tarwaka, Bakri SH, Sudiajeng L. Ergonomi untuk Keselamatan, Kesehatan Kerja dan Produktivitas [Internet]. 2004. 120-121 p. Available from: http://shadibakri.uniba.ac.id/wpcontent/uploads/2016/03/Buku- 
Ergonomi.pdf

9. McAtamney L, Hignett S. Handbook of Human factors and Ergonomics Methods. 2004. 71-73 p.

10. Straker LM. Body Discomfort: Assessment tools. Occup Ergon Eng Adm Control. 2005;26-40.

11. Long MH, Johnston V, Bogossian FE. Helping women but hurting ourselves? Neck and upper back musculoskeletal symptoms in a cohort of Australian Midwives. Midwifery. Elsevier; 2013;29(4):359-67.

12. Stichler JF, Feiler JL, Chase K. Understanding Risks of Workplace Injury in Labor and Delivery. JOGNN. 2011;41:71-81.

13. Nowotny-Czupryna O, Naworska B, Brzęk A, Nowotny J, Famuła A, Kmita $B$, et al. Professional experience and ergonomic aspects of midwives' work. Int J Occup Med Environ Health. 2012;25(3):265-74.

14. wirakusumah F. Metode Penelitian. In: konsistensi penelitian. Jakarta: refika aditama; 2011. p. 56-7.

15. Barbe MF, Barr AE. Inflammation and the pathophysiology of work-related musculoskeletal disorders. Brain Behav Immun. 2006;20:423-9.

16. Alexopoulos, Evangelos C., Burdorf, Alex, Kalokerinou A. International archives of occupational and environmental health. Int Arch Occup Environ Health. 2003; Volume 76:28994. 